\title{
Strategies of the Game on the Use of BOT Model for the Eco-tourism Enterprises in the Infrastructure Development of Ecological Tourism
}

\author{
Yang Peitao, Wang Shuai and Zhou Ting \\ Dept. of Graduates, Central South University Forestry and Technical, Changsha Hunan, 410004
}

\begin{abstract}
Based on BOT model in the eco-tourism infrastructure and from the perspective of the Eco-tourism Enterprises, this article analyzes the game of the concession periods, the game of the costs and the game between the two to achieve the Maximization of Eco-tourism Enterprises' profits by using some related theories and methods.
\end{abstract}

Key Words: Eco-tourism infrastructure, Eco-tourism Enterprises ,BOT, Game

\section{Introduction}

With the rapid development of economy, the Great Western Development and the implementation of the strategy of central China, the development of eco-tourism industry (Lachapelle, P. (1998), Teece D. 1997,Kumaraswamy et al. 2001)is bound to become a new economic growth point, the investment demand gap of eco-tourism facilities will increase, relying solely on government investment can not meet the huge demand of the growing eco-tourism facilities. Tourism enterprises actively participate in the construction and operation of the eco-tourism facilities (Michael and Charles 2003)will certainly become an important way to solve the investment demand gap of the eco-tourism facilities, but the best path that tourism enterprises participate in the construction and operation of the eco-tourist facilities is to introduce the BOT model. The BOT model (YANG H and MENG Q 2002,Shengfeng L et al. 2008,Xinmin Z 2010)is that government departments will firstly transfer the concession of the eco-tourism facilities to tourism enterprises in a certain period of time, then Tourism enterprises are responsible for the construction and operation of the project, and charge fees to repay the debt or profit according to the specific way, finally Tourism enterprises will transfer the project of the eco-tourism facilities to the government departments with free or pre-agreed price until the expiration of the ecological tourism projects. Seen that the determination of the duration of the concession of the construction projects of the eco-tourism facilities will be the core issue that affects the revenue between tourism enterprises and government departments. From the perspective of tourism enterprises, For the BOT model in the construction projects of eco-tourism facilities, Using the correlation theories and method of game, the article analyses the game of the concession period, the cost and the relationship between them.

\section{The game of The concession duration when eco-tourism enterprises make application of BOT model in the construction of tourist facilities.}

The most important game between tourism enterprises and government departments in the construction projects of the eco-tourism facilities is the concession of the game, Including the scope of the powers of the concession, the concession period, financing, operation mode, toll pricing and more. Tourism enterprises hope to extend the concession period of the project of the eco-tourism facilities to achieve the maximization of the profits. However, government departments always try to shorten the concession 
period to maximize the effectiveness of eco-tourism facilities. Assumed that $T_{A}$ is the minimum acceptable concession period to achieve the expected profit of the tourism enterprises and TB is the concession period to achieve the maximum expected utility allowed by the government departments, so $T_{A}-T_{B}$ is the respective interests of the game space between Tourism enterprises and government departments. Considering the subsidy of the government departments, actually increasing the direct value of eco-tourism facility, the corresponding concession boundaries in tourism enterprises will be left to the $T_{C}$, then the game space has increased from $T_{A}-T_{B}$ to $T_{C}-T_{B}$. Figure 1 describes the best strategy for tourism enterprises that make the application of BOT model in the construction of eco-tourism facilities to take the game in respect of a concession period with government departments. It can be seen from Figure 1 that only if the respective benefits or profits accepted by both tourism enterprises and Government departments of the game is the best value, both sides get the best TY of the concession period. In addition, tourism enterprises not only have increased the willingness to invest and have guaranteed the minimum level of debt repayment, but also have improved the ability for guarding against risks in order to ensure that the construction period and the quality of the eco-tourism facilities.

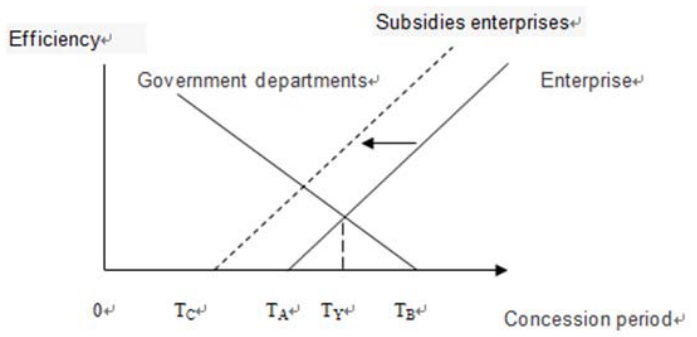

Figure 1 the game of the concession period in the application of BOT model in the eco-tourism infrastructure of the tourism enterprises

\section{Cost game of the enterprises in the application of BOT model of the Eco-tourism facility construction}

In the Investment in eco-tourism facilities, it is assumed that all content can be quantified in the concession agreement and are reflected in the total profits of BOT projects, profits can only be allocated between tourism enterprises and Government departments, without regard to other profit distribution scheme. A period of the application of BOT model of the Eco-tourism facility construction is $\mathrm{N}$ years, the economic life is Te years, the total cost of the Eco-tourism enterprises (CT)can be divided into the construction cost $(\mathrm{Cn})$ and maintenance cost $(\mathrm{CV})$, in which $\mathrm{CN}$ is a constant, $\mathrm{Cv}$ is equal to $\mathrm{KC}-\mathrm{a},(\mathrm{k}>0, \mathrm{a}>0), \mathrm{r}$ is for annual interest rate. that is
$\mathrm{C}_{\mathrm{T}=} \mathrm{C}_{\mathrm{N}}+\mathrm{C}_{\mathrm{V}=} \sum_{i=1}^{N} c_{i}\left(\frac{1}{1+r}\right)_{i-1}+\sum_{i=N+1}^{T} c_{i}\left(\frac{1}{1+r}\right)_{i-1} \quad$ In General, the maintenance costs of the eco-tourism facility $\mathrm{CV}$ will decrease with the increase of the construction costs $\mathrm{CN}$, because the Higher the construction costs are, the better the quality of the BOT projects of the eco-tourism infrastructure is, the maintenance costs in the later are the lower. On the contrary, the less the construction costs of the tourism enterprises in the construction of eco-tourism facility are ,the higher the maintenance costs in the construction of eco-tourism facility construction are , the longer the privilege period is ,the more the total costs of the investment will be .This is against the goals the tourism enterprises to maximize profits.

Because the tourism enterprises apply BOT to ecotourism facilities construction in order to reap the maximum profits at the minimum cost within the period of the concession in the project. They must make clear the relation between the total costs of the investment and the BOT concession for eco-tourism facility construction projects during the game. The game relation between the total investment costs, maintenance costs and concession period for BOT eco-tourism facility construction project can be described in Figure 2.

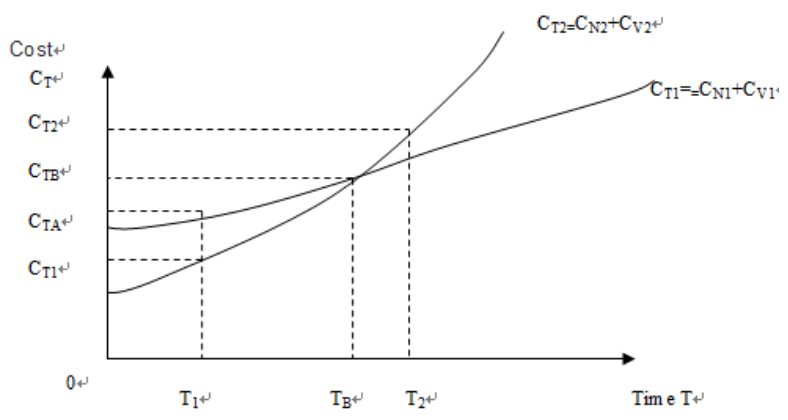

Figure 2 the costs game in the application of BOT model in the eco-tourism infrastructure of the tourism enterprises

From Figure (2) it can be seen when the concession period is less than TB the tourism enterprises will choose the cost CT2 and the total cost is less. If the concession period is equal to $\mathrm{TB}$, tourism enterprises will choose the cost CT1 or CT2, and both of the total costs are equal. But when selecting CT1 tourism enterprises have higher construction costs and lower maintenance costs, selecting the CT2 tourism enterprises have higher maintenance costs and lower construction costs; If the duration of the concession cost is greater than TB and tourism enterprises selects the cost CT1, the total cost is smaller.. 
It appears that the concession period in the BOT projects of the eco-tourism facilities is too short, the tourism enterprises in the BOT projects will choose a lower construction cost, which will affect the quality of the eco-tourism facility construction, So that the high maintenance costs of government departments will be very high and the income of government departments will be reduced after the ecological tourist facilities are transferred from the tourism enterprises over to the government. But if the concession of the BOT projects in the construction of the ecological tourism infrastructure, the income of the tourism enterprises will increase and the income of the government departments will decrease, in order to reduce the government initiative in introducing BOT mode in the construction of eco-tourism facilities. Therefore, the tourism enterprises should determine their own best cost strategy in the particular concession period in the BOT projects of the ecological tourism infrastructure not only to achieve their maximum profit, and must give the dual attention to the optimal of the government income, thus achieving the win-win pattern of tourism enterprises and Government departments in the BOT model of the eco-tourism facilities.

\section{The dynamic game between the cost and the concession in the construction of the ecological tourism facilities where tourism enterprises use the BOT mode.}

Due to considering only the direct benefits of the construction of ecological tourism facilities for the tourism enterprises and government departments and not taking into account the indirect usefulness of the eco-tourism facility construction, assuming that the total benefits of the eco-tourism facility construction as a whole are a constant $\mathrm{R}$, including the direct benefits R2 to the tourism Enterprises and the direct gains R1 to government departments, the establishments of the decision models of the tourism enterprise are as follows:

$$
\begin{aligned}
& \underset{T}{M A X} \int_{0}^{T}\left(R_{1}-C_{N}-C v\right) d t \\
& \text { s.t } \int_{T}^{T e}\left(R-R_{1}-C v\right) d t \geq \varpi
\end{aligned}
$$

Formula (1) refers to the function of the Maximum utility for the tourism enterprises when they choose the concession period T, Formula (2) is the participation constraint in the utility function of the tourism enterprises, namely the expected utility that government departments accept the contract with the tourism enterprises cannot be less than the maximum expected utility or the opportunity cost $\varpi$ hat government departments don't accept the contract with the tourism enterprises. According to formula (1) and formula (2), a Lagrange function is constructed and the Lagrange Constant is $\lambda$, here is:

$$
\begin{aligned}
& \mathrm{L}(\mathrm{T}, \quad \lambda)=\int_{0}^{T}\left(R_{1}-C N-C v\right) d t+\lambda \quad[\text { s.t. } \\
& \left.\int_{T}^{T e}\left(R-R_{1}-C v\right) d t-\varpi\right]
\end{aligned}
$$

For the Lagrange function, the optimizations to the formula (3) are:

$$
(\lambda+1) \mathrm{R}_{1}+(\lambda-1) \mathrm{KC}^{-\mathrm{a}}-\left(\lambda \mathrm{R}+\mathrm{C}_{\mathrm{N}}\right)=0
$$

$$
(\mathrm{Te}-\mathrm{T})\left(\mathrm{R}-\mathrm{R}_{1}-\mathrm{KC}^{-\mathrm{a}}\right)-\varpi=0
$$

According to the analyses of the formula (4) and the formula (5), the optimal decision of

The concession period for the tourism enterprises to choose the BOT model in the ecological construction of tourism infrastructure is :

$$
\mathrm{T}=\mathrm{Te} \frac{\varpi}{R-R 1-K C^{-a}}
$$

The optimization decision-making of construction cost of tourism enterprises is $\mathrm{CN}$,

$$
\mathrm{CN}=(\mathrm{aKT}) 1 /(a+1)=\left[\frac{\left.a K T_{e}\left(R_{2}-K C^{-a}\right)-a K \varpi\right]}{R_{2}-K C^{-a}} 1 /(a+1)\right.
$$

Thus, it is concluded that The optimization decision-making of construction cost of tourism enterprises is $\mathrm{CN}$ when the concession period of the tourism enterprises in the ecological construction of tourism facilities is $\mathrm{T}$.

\section{Conclusions}

The concession period of Ecological construction of tourism facilities using the BOT model is very important, the Length of the concession directly determines the interests of tourism enterprises and Government departments, but also influences the cost and quality on the ecological construction of tourism infrastructure. By using the game theory, This paper examines the decision model of the concession period when the tourism enterprises use the BOT model in the ecological construction of tourism infrastructure, and analyses the game relationship between the construction cost and the concession period of the construction of eco-tourism facilities. Namely concession period is short, the tourism enterprise will choose the smallest construction costs to decline the quality of the construction of eco-tourism facilities and increase the cost of the maintenance. According to the income of government departments, the tourism enterprises should choose the best concession period to obtain the maximum benefit, ensuring the quality and technology of the BOT projects in the construction of eco-tourism facilities. It is a good theoretical significance and practical value that the systematic theory and methods on the BOT model in the construction of eco-tourism facilities are established. 


\section{Acknowledgements}

Authors would like to thank professor Xiaoping LIAO at Central South University Forestry and Technical who provides language help.

\section{Reference}

1. Teece D.,Pisano

G.

\&Shuen

A.DynamicCapabilities and Strategic Management[M].Strategic Management Journal, 1997,18(7):509-533.

2. Lachapelle, P. Managing sanitation in protected areas: problems and challenges in Sagarmatha (Mt. Everest) National Park, Nepal. [J].Himalayan Research Bulletin, 1998:18, 53-57.

3. Kumaraswamy MM,zhang XQ.Govermental role in BOT-led infrastructure development [J].international journal of project management,2001,19:195-205

4. Michael J G, Charles Y J C. Valuation techniques for infrastructure investment decision $[\mathrm{J}]$. Construction Management and Economics, 2003, 22: 373-383.

5. Xinmin Z. Effects of Operating BOT Model in Rural Eco-tourism on the New Countryside Construction $[\mathrm{J}]$. Reformation and Strategy,2010,11:102-104

6. Shengfeng L. ,Daopin C. Lingyan H. The Risks of Applying BOT Model into the West Tourist Sites Exploitation [J]. Business research ,2008,2:14-18

7. Darrin Grimsey, Mervyn K.Lewis. Evaluating the risk of public private partnerships for infrastructure projects [J].International Journal of Prject Management, 2002,20:107 118.

8. YANG H, MENG Q. A note on highway pricing and capacity choice in a road network under a build-operate-transfer scheme [J]. Transportation Research Part A, 2002, 36:659-663.

9. FREDI L, GUSTAVO K. South Israel 100 millionm3/y seawater desalination facility: build, operate and transfer (BOT) project [J]. Desalination,2003,156:29-37.

10. SMITH Nigel, ZHAO Hao, ZHU Yi-ran. The Huai-bei power plant and its implications for the
Chinese BOT market [J]. International $\mathrm{J}$ of Project Management, 2004, 22:407-413 